Review Article

\title{
BRIEF REVIEW ON THERMOPHILIC BACTERIA AND THEIR APPLICATIONS
}

\author{
ROHIT SHANKAR MANE ${ }^{*}$, ASAMA NADAF ${ }^{2}$ \\ ${ }^{1}$ Unimech Research and Testing Centre, Unimech Healthcare, Bangalore, 560058, India, ${ }^{2}$ Department of Microbiology, Mahavir \\ Mahavidyalaya, Kolhapur, 416006, India \\ *Email: rohit.mane@unimechhealthcare.com
}

Received: 12 Sep 2021, Revised and Accepted: 15 Nov 2021

\begin{abstract}
Enzymes from incredibly thermophilic microorganisms have been of innovative interest for quite a while in view of their capacity to catalyses responses of modern importance at raised temperatures. Most of the potential bioprospecting is at present identified with the investigation of the extremophiles and their likely use in modern cycles. As of late microbial enzymes discover applications in different businesses and comprise a significant gathering of modern enzymes. Present review article reveals basics of thermophilic bacteria and their applications with thermostability.
\end{abstract}

Keywords: Thermophiles, Ecology, Thermoenzymes, Thermostability, Applications

(C) 2022 The Authors. Published by Innovare Academic Sciences Pvt Ltd. This is an open access article under the CC BY license (https://creativecommons.org/licenses/by/4.0/) DOI: https://dx.doi.org/10.22159/ijcpr.2022v14i1.44107 Journal homepage: https://innovareacademics.in/journals/index.php/ijcpr

\section{INTRODUCTION}

Organic entities equipped for living at high temperatures have held a specific interest for researcher and natural chemists, as they exist at temperatures where their proteins and nucleic acids would be relied upon to be denatured [1]. Hotness adoring microorganisms, or thermophiles, are among the best examined of the extremophiles. The order of living life forms dependent on their connection to temperature has consistently been considered as the most essential component of organic methodical [2]. For the most part, the ideal temperature for development of earthbound microorganisms is between 25-35 ${ }^{\circ} \mathrm{C}$. Microorganisms were gathered into three classifications dependent on their ideal temperature, psychrophiles that have a underneath $20{ }^{\circ} \mathrm{C}$, mesophiles that develop ideally between $20{ }^{\circ} \mathrm{C}$ to $40{ }^{\circ} \mathrm{C}$ and thermophiles between 50 to $80{ }^{\circ} \mathrm{C}$. Generally, life forms with a maximal development temperature $\mathrm{T}_{\max }$ (i.e., above which no development happens) higher than $50{ }^{\circ} \mathrm{C}$ have been depicted as thermophiles [3, 4]. Brock in 1969 proposed defining the limit of thermophiles above $60{ }^{\circ} \mathrm{C}$ dependent on two contentions. To start with, temperatures underneath this limit are normal in nature, though higher temperatures are mostly connected with geothermal and modern exercises. Further, no multicellular creatures or plants have been found to endure temperatures above $50{ }^{\circ} \mathrm{C}$. Thermophilic microorganisms have a place with Archaea and Bacteria are remarkable in variation to as high as $121{ }^{\circ} \mathrm{C}$ temperature [5], which is threatening to standard life. Thermophiles are grouped in various classes concurring to their temperature necessity. Thermophiles were arranged as life forms with a temperature least of about room temperature $\left(25{ }^{\circ} \mathrm{C}\right)$, Orthothermophiles as microorganisms with a temperature most extreme over the temperature of protein coagulation $\left(60-70^{\circ} \mathrm{C}\right)$ and the thermotolerants as life forms with a temperature limit of 50-55 ${ }^{\circ} \mathrm{C}$, yet additionally develop well at room temperature. Thermophiles are additionally isolated into two gatherings as first is valid thermophiles, which showed ideal development at $60-70{ }^{\circ} \mathrm{C}$ and no development, or follow development, under 40 to $45^{\circ} \mathrm{C}$. The second is facultative thermophiles, which showed development at $25^{\circ} \mathrm{C}$ and have their ideal temperature for development and endurance is 50$55{ }^{\circ} \mathrm{C}$, and most extreme $60{ }^{\circ} \mathrm{C}$. Thermophiles are likewise named severe thermophiles, which showed development above $55{ }^{\circ} \mathrm{C}$; thermotolerant showed ideal development at temperature between $40-50{ }^{\circ} \mathrm{C}$ and commit thermophiles showed development at $55{ }^{\circ} \mathrm{C}$, however not at $37^{\circ} \mathrm{C}[6]$. As of now, thermophiles are characterized into moderate thermophiles (ideal development $50-60{ }^{\circ} \mathrm{C}$ ), outrageous thermophiles (ideal development $60-80{ }^{\circ} \mathrm{C}$ ) and hyperthermophiles (ideal development $80-110 \quad{ }^{\circ} \mathrm{C}$ ). A few researchers made a solitary gathering of hyper thermophiles and outrageous thermophiles. In light of their ideal temperature for development, a few thermophilic microscopic organisms also, archaebacteria have been named moderate thermophiles (Bacillus caldolyticus, Geobacillus stearothermophilus, Thermoactinomyces vulgaris, Clostridium thermohydrosulfuricum, Thermoanaerobacter ethanolicus, Thermoplasma acidophilum), outrageous themophiles (Thermus aquaticus, Thermodesulfobacterium collective, Sulfolobus acidocaldarius, Thermomicrobium roseum Dictyoglomus thermophilum, Methanococcus vulcanicus, Sulfurococcus, mirabilis, Thermotoga mritima) and hyperthermophiles (Methanoccus jannaschii, Acidianus hellfires, Archaeoglobus profundus, Methanopyrus kandleri, Pyrobaculum islandicum, Pyrococcus furiosus, Pyrodictiumoccultum, Pyrolobus fumarii, Thermococcus littoralis, Ignicoccus islandicum, Nannoarchaeum equitans Geobacillus sp.) [79]. The greater part of the thermophiles has been secluded from manures, sun-warmed soils, earthly underground aquifers, submarine aqueous vents and geothermally warmed oil saves and oil wells. The first extremophile equipped for development at temperatures more noteworthy than $70{ }^{\circ} \mathrm{C}$ was a bacterium, presently called Thermus aquaticus that would later make conceivable the inescapable utilization of a progressive innovation the polymerase chain response. Concerning a similar time, the first hyperthermophile $[10,11]$.

\section{Habitat of thermophiles}

Regular geothermal regions are generally conveyed across the globe. Natural aquifers are framed because of the development of boiling water from the world's outside through shortcomings made by structural development or volcanic ejection. Earthly surface conditions incorporate natural aquifers that are near unbiased $\mathrm{pH}$, or acidic and sulfurous, or rich in iron. Hot underground regions are different and goes from volcanically warmed conditions to those, for example, the Great Artesian Basin in Australia that are warmed by ethicalness of their profundity. Natural aquifers could be fundamental, nonpartisan, or acidic [12]. Be that as it may, the most various are those with soluble $\mathrm{pH}$, normally connected with volcanic or structural movement. Acidic underground aquifers, for example, that of the Yellowstone caldera are related with dynamic volcanoes or shallow magma pools [13]. The $\mathrm{pH}$ of geothermal springs mirrors their biodiversity, for example, in acidic underground aquifers, acidophiles such as Sulfulobus flourish and in impartial or moderate natural aquifers a different number of thermophiles like Thermoproteus, Pyrobaculum, Methanothermus, Desulforococcus and Thermofilum exist. Submarine conditions incorporate volcanic and aqueous vents. The last are frequently portrayed as dark smokers inferable from the precipitation of minerals when hot, mineral-rich 
volcanic liquids meet cold sea waters $\left(5^{\circ} \mathrm{C}\right)$. The current record for high-temperature development is held by the archaeon Pyrolobus fumarii, which can develop at $113^{\circ} \mathrm{C}[14]$.

\section{Earthbound natural aquifers}

Earthbound geothermal regions can be for the most part isolated into two classes as indicated by the nature of the hotness source and $\mathrm{pH}$.

\section{High-temperature fields}

High temperature fields are situated inside the dynamic volcanic zones and magma chamber fills in as the hotness source [15]. They are for the most part on key position. Torfajokull east of Hekla, Grimsvotn in the Vatnajokull ice sheet, and Hengill close to Reykjavik, Kerlingarfjoll, Namafjall close to Myvatn, Kverkfjoll on the north side of Vatnajokull furthermore, Krisuvik south of Reykjavik are the primary hightemperature regions. Around there, steam and volcanic gases are produced at the surface and the water temperature comes to 150 to $350{ }^{\circ} \mathrm{C}$. The most noteworthy, recorded temperature was $386{ }^{\circ} \mathrm{C}$. Icelandic underground aquifers have high sulfide fixations $\left(30 \mathrm{mg} / \mathrm{L}^{-1}\right)$ and thick bacterial mats are framed with accelerated sulfur and make fabulous dazzling yellow or white tones [16].

\section{Low-temperature fields}

The low temperature underground aquifer fields are situated outside the dynamic volcanic zones. The outer layer of lowtemperature fields is generally covered with underground aquifers and fountains. The boiling water of these spaces is basic. Generally, the synthetic substance of low-temperature water is like the compound substance of freshwater hence it is feasible to utilize the low-temperature water. Profound magma streams, furthermore, dead magma chambers fill in as hotness sources and the water temperature is typically beneath $150{ }^{\circ} \mathrm{C}$ at profundities of 500 to $3000 \mathrm{~m}$ [17]. The hottest water openings in low temperature fields having temperature $75-100^{\circ} \mathrm{C}$ are called underground aquifers.

\section{Underground natural aquifers}

Deep silt, rocks and minerals offer conditions for life that are totally different from earthbound and amphibian territories. Water ordinarily contains $\mathrm{H}_{2}, \mathrm{CH}_{4}$ and $\mathrm{CO}_{2}$ that advance chemolithoautotrophic life however microbial development rates is low. Steam and water are gathered in boreholes 1500 to $2000 \mathrm{~m}$ profound, and temperatures are running between 50 to $130{ }^{\circ} \mathrm{C}$ [18].

\section{Marine and earthbound oil repositories}

Oil fields are considered as new living spaces for thermophiles. Contingent upon the geographic area, repositories have temperatures going from 60 to $130{ }^{\circ} \mathrm{C}$ and pressures somewhere in the range of 15 and $40 \mathrm{MPa}$ sea floor, down to a few kilometres. The liquid is extremely hot (250 to $400{ }^{\circ} \mathrm{C}$ ), acidic, wealthy in metals (iron), $\mathrm{CH}_{4}$ and $\mathrm{H}_{2} \mathrm{~S}$. In case there is blending of aqueous liquid and cold seawater not long before outflow, its temperature is 5 to $100{ }^{\circ} \mathrm{C}$ and in case there is no blending, the temperatures of liquid vents is $350{ }^{\circ} \mathrm{C}$ or above. The remote ocean vents are otherwise called dark smokers, because of the steady release of accelerated minerals in seawater that take the part of thick, dark mists [19]. Most of the known aqueous vent can be found at profundities more prominent than $3500 \mathrm{~m}$ and as shallow as $400 \mathrm{~m}$.

\section{other geothermal natural surroundings}

Steady hot environments other than geothermal are not many in nature. Sunlight based warmed lakes and naturally warmed fertilizers, feed and compost might cause high temperature. Man-made, hot conditions, for example, boiling water pipelines consuming coal decline heaps, squanders from treatment plants or modern cycles in the food or substance industry have additionally been made. A few notable thermophiles, for example, a few Thermus animal varieties, Thermoplasma acidophilum, have been essentially segregated from those man-made hot frameworks. For example, Thermus scotoductus, a shade delivering bar was separated first from hot regular water in Iceland [20].

\section{Thermophilic bacteria}

The thermophilic bacterial agents showed ideal development underneath temperature $75{ }^{\circ} \mathrm{C}$, aside from Thermotogae and
Aquificae have ideal temperature above $85^{\circ} \mathrm{C}$. The $\mathrm{pH}$ range for bacterial thermophiles is 5-9, with few special cases like Hydrogenobaculum spp. or then again Bacillus species. The Aquificae, Thermotogae, Thermodesulfobacteria, Thermo-microbia and Thermales are thermophilic families. Aquificae species are thermophilic high impact, commit, chemolithoautotrophic microbes and utilized $\mathrm{H}_{2}$ or diminished sulfur compounds as energy sources [1]. The Thermotogae, are anaerobic and fermentative species. They are Gram negative cells with an unmistakable external sheath-like envelope of "frock". The Thermodesulfobacteria cells are pole formed, rigorously anaerobic, chemoheterotrophic displaying a unique sulfate-lessening digestion [2]. The phylum Thermomicrobia cells are mandatory oxygen consuming and become distinctly on complex supplements. The request Thermales addresses Thermus aquaticus, separated from the Yellowstone Park in the USA. The Thermales are transcendently vigorous and heterotrophic. The Thermus sort can be found in different conditions, for example, hot faucet water [3], thermally dirtied streams or fertilizer heaps and normal aqueous regions, marine aqueous vents, and shallow marine underground aquifers. Different genera create the request Thermales, for example, Meiothermus, and Marinithermus, Oceanithermus and Vulcanithermus all are disengaged from profound marine vents. The thermophilic Gram-up-sides are dispersed among 22 genera, and 20 are only thermophilic [4, 5]. The Cyanobacteria are mesophilic oxygenic photosynthetic prokaryotes with the couple of special cases of moderate thermophiles like Fischerella or Oscillatoria furthermore, Synechococcus which becomes ideally above $55{ }^{\circ} \mathrm{C}$. The genera Rhodothermus furthermore, Thermonema are the interesting thermophilic delegates among the Cytophaga/Flexibacter/Bacteroides bunch. Rhodothermus becomes above $70^{\circ} \mathrm{C}$ and needs at least $1 \%$ salt focus for development [6]. It has been utilized broadly as a wellspring of new compounds Thermonema is a moderate thermo-halophile with at $65^{\circ} \mathrm{C}$. The class has been accounted for from New Zealand, Italy, and Iceland. The purple microbes or Proteobacteria, thermophilic genera dissipated among the, $\beta, \gamma, \delta$ and $\varepsilon$-developments coincide with both mesophilic and psychrophilic agents. The $\beta$-proteobacterial genera are becoming stringently under anaerobic conditions. The thermophilic ones are the hydrogen-oxidizing Hydrogenophilus and the sulfuroxidizing Thermothrix, just as the sulfur-reducers Desulfurella and Thermodesulfobacterium. Delegates of the $\varepsilon$-development are generally moderate thermophiles with Topt fluctuating around 55 to $65^{\circ} \mathrm{C}$. The Geobacillus spp (detached from underground aquifers, fertilizer, geothermal soil, raw petroleum, gold mine and profound sea dregs) announced worldwide and evaluated $[7,8]$.

\section{Thermoenzymes}

Enzymes created by thermophiles and hyperthermophiles are ideally dynamic at high temperatures, somewhere in the range of 60 and $125^{\circ} \mathrm{C}$ and impervious to irreversible inactivation at raised temperatures are known as thermoenzymes. Thermozymes offer different biotechnological and modern benefits over mesophilic proteins. They are simpler to decontaminate by heat treatment, higher protection from synthetic denaturants (solvents and guanidinium hydrochloride) and withstand higher substrate focuses [21]. Since of their soundness at raised temperature, thermozyme responses are less powerless to microbial pollution and frequently show higher response rates than mesozyme catalyzed responses. Considering these significant benefits, thermozymes are drawing in much modern interest. Moreover, thermozymes can be utilized as models for comprehension thermo soundness. Consequently, distinguishing underlying highlights associated with strength of thermozymes is fundamental for a hypothetical portrayal of the physico-compound standards adding to protein strength and collapsing $[11,22]$. Besides, this data is fundamental likewise for planning more steady proteins for modern cycles. The principle benefit of thermozymes is their high strength at raised temperatures which is valuable for a huge assortment of modern cycles. The increment of temperature impacts the bioavailability and expanded dissolvability of numerous polymeric substrates or natural substrate $[12,23]$. The height of temperature likewise related with expansion in dispersion of natural mixtures, decline in thickness, further developed exchange rates and subsequently expanded response rates. Additionally, another benefit is that it likewise decreases the 
hazard of microbial pollution as every one of the pathogenic microscopic organisms and saprophytes are killed at temperature above $70{ }^{\circ} \mathrm{C}$ and lessen number of microscopic organisms which cause defilement of food processes. Variables adding to steadiness incorporate extra intermolecular cooperation's (for example hydrogen bonds, electrostatic communications, hydrophobic associations, disulfide bonds, metal restricting) and great general conformational structure (for example more inflexible, high pressing thickness; conformational strain discharge [24]; steadiness of ahelix; decreased entropy of unfurling, ideal charge example or particle pair and oligomer development). Electrostatic connections increment the quantity of salt extensions in proteins of thermophiles as contrast with mesophilic proteins. In thermophilic proteins, the measure of Glu, Arg and Lys are higher in the helices, which lead to expansion in control build ups, upgrading thermo resistance of proteins in hyper thermophilic microorganisms. Hydrophobic powers are significant supporters of atomic collapsing and thermostability $[13,15]$. Most extreme pressing proficiency of a catalyst can be accomplished by filling holes in the protein centre and lead to expand the centre hydrophobicity. The ribonuclease HI from Escherichia coli has a pit close to inside the protein centre. Presentation of a methyl bunch in the cavity expanded hydrophobic cooperation inside the protein centre and thusly upgraded protein security. Higher measure of alanine, isoleucine and proline gives additional security to circles and tighter the pressing in hydrophobic centres. Proteins are balanced out by disulphide spans through an entropic impact. Disulphide spans decline the entropy of protein's unfurled state. The disulphide bond interfaces the C-end of helix1 at 20 and 27 position, following $\beta$-turns which lead to the thermo soundness of glucoamylase. Metals are known to balance out and enact proteins. An investigation of $B$. licheniformis xylose isomerase (BLXI) showed settling powers are related with the presence of metals in the holoenzyme. The energy of actuation for irreversible inactivation was affected by the presence of metal particle. The actuation energy went from 342 (apoenzyme) to $1166 \mathrm{~kJ} / \mathrm{mol}$ (Co2+enzyme) [25]. By and large, mesophilic proteins are inactivated at raised temperature due to covalent adjustments. This kind of inactivation might be forestalled by replacement of explicit different sorts of polysaccharide corrupting compounds like amylases, cellulases, pullulanases, xylanases, mannanase, pectinases and chitinases, lipases, esterases, proteases and phytases have been portrayed from amazingly thermophilies and hyperthermophiles. Countless thermozymes are required by businesses. Starch, material, drug, calfskin, mash and paper, cleanser, food also, feed businesses are the principle client of thermophilic compounds [26]. The starch business is perhaps the biggest client of thermostable amylolytic proteins. Amylases, glucoamylases and isoamylases or pullulanases are utilized in starch ventures for the hydrolysis and adjustment of starch to create glucose and different items. Amylolytic proteins are likewise utilized in baking, material, and paper businesses. Cellulolytic proteins are utilized in cleansers for shading lighting up and mellowing of materials, biostoning of pants, expulsion of polyphenolic substances from juices, mash and paper businesses and pre-treatment of plant biomass [27]. These days, bio cleansers contain proteins like amylase, protease, cellulase and lipase, utilizing variations that are safe to unforgiving conditions. Lipases are additionally utilized in different cycles, for instance, fat hydrolysis, esterification, interesterification, trans-esterification and natural biosynthesis. Different utilizations of lipase incorporate the expulsion of pitch from mash delivered in the paper business, hydrolysis of milk fat in the dairy business, expulsion of noncellulosic contaminations from crude cotton before additional handling into coloured and completed items, expulsion of subcutaneous fat in the cowhide business and assembling of medications in the drug business [28].

\section{Thermostability}

Warm opposition of catalysts is controlled by free energy utilization essential for change of particles from collapsed to unfurled state. Slight changes of amino acids dissemination and groupings increment the quantity of balancing out cooperation's in the collapsed protein, for example, extra particle sets, disulphide spans, hydrogen bonds and hydrophobic connections. Notwithstanding sidechain connections, thermophilic and hyperthermophiles microorganisms embrace different procedures for balancing out proteins. This might be accomplished by filling pits in the atomic design of the proteins, shortening of the circles and decrease of open hydrophilic surface region [29]. Different changes include metal particle restricting furthermore, reduced measure of build-up's helpless to deamidation or oxidation. Besides, some thermozymes contain thermolabile deposits in area in which they are not powerless to debasement. Thermostability of certain proteins can be guaranteed by natural components, e. g., expanded intracellular salts furthermore, protein focuses and combination of various stabilizers. Be that as it may, there are no widespread elements or their mixes that might be liable for warm dependability of proteins [30]. Besides, many elements engaged with thermostabilization of solvent proteins don't show up in the event of film proteins. Even though, variation of thermozymes to act at raised temperatures is mostly accomplished by trade of scarcely any amino corrosive build ups and additionally their diverse limitation in particle, the homologous thermostable and thermolabile catalysts are comparative and have the equivalent reactant components. Higher obstruction of thermozymes as contrasted and their mesophilic partners is the aftereffect of expanded inflexibility, which jelly their chemically dynamic construction, yet prompts diminished movement at lower temperatures. Nonetheless, now, and again, thermozymes are more dynamic than their mesophilic partners even at low temperatures. Such marvel proposes that their particles show nearby adaptability in the space of synergist site with generally inflexibility of the remainder of the protein $[15,19,21]$. It is fascinating to take note of that a large portion of the heat safe catalysts show maximal action above the ideal development temperature of the microorganisms from which they are separated.

\section{Applications of thermoenzymes}

As of now, just scarcely any thermostable proteases are commercially accessible. One of them is alcalase disconnected from Bacillus licheniformis [1]. The significant element of this planning is subtilisin, which is an endoprotease of serine type, displaying most elevated action at $60{ }^{\circ} \mathrm{C}$ and $\mathrm{pH}$ of 8.3. Alcalase discovered numerous applications in the food business, e. g., by reason of their low particularity towards various proteins from plant and creature sources. For instance, this protein is significant in the handling of soy supper which brings about dissolvable, [2] non-severe hydrolysate, utilized as part of protein-sustained sodas [4] and dietetic food [5]. Alcalase is additionally helpful for recuperation of proteins from results of the meat and fish industry also, from shellfish shell squander during chitin creation [12]. Moreover, thermostable proteases that are impervious to anionic or non-ionic surfactants and are dynamic at temperatures above $60{ }^{\circ} \mathrm{C}$ discovered application as part of dishwashing cleansers. Such proteins can be additionally utilized for cleaning ultrafiltration layers at high temperatures, expanding the effectiveness of this cycle. The other expected use of hotness safe proteases is meat softening. It is because of the extraordinary contrast of enzymatic action at moderate and high temperatures $[6,9,11,21]$. The mesophilic proteases infused into the tissue show a lingering action during the entire time of post-butcher stockpiling of the meat slices prompting an unreasonable discontinuity of the protein atoms. The utilization of compounds with a fundamental action as it were during cooking permits the stoppage of proteolysis just by cooling. The steadiness of hotness safe proteases in fluid/natural and nonaqueous media prompts the adjustment of the response equilibria, making new peptide bonds. Such converse responses might be utilized to work on nourishing quality and usefulness of protein hydrolyzates and to lessen their sharpness $[3,7,9,13]$. It is accomplished by expanded sub-atomic load of peptides just as by presentation of beneficial amino corrosive build-ups. Among the thermostable proteases presently utilized on a modern scale, immobilized thermolysin from Bacillus thermoproteolyticus is engaged with the amalgamation of aspartylphenylalanine-1-methyl ester, known as aspartame. This item is ordinarily utilized as sugar in some low-caloric food and drinks. Enzymatic combination dispenses with tainting of the item by nonsweet and unpleasant isomers. Poultry industry creates a lot of quills. Customarily, this side-effect is debased by antacid hydrolysis and steam pressure cooking. Such method of handling annihilates some fundamental amino acids and lead to development of non-nutritive lysinoalanine and lantionine $[16,19]$. By this explanation, an incredible 
importance has non-contaminating, biotechnological use of keratincontaining squanders. In any case, the generally created proteases proved unable debase keratin. It is brought about by firmly stuffed fibre design of keratin, settled by an enormous number of disulphide and hydrogen bonds just as by hydrophobic cooperations. This insoluble protein can be separated by certain microorganisms discharging keratinases (EC 3.4.99.11) and acquired hydrolyzates have been utilized as manures and dietary protein supplement for creature feed. In expansion, keratinases have likely use as dehairing specialist in cowhide and restorative industry, and as part of cleansers and consumable movies. As of late, there have been many reports on filtration of keratinases from microorganisms [16, 19]. Contingent upon protease source, keratinolytic catalysts show distinctive movement and substrate particularity. For example, keratinase from B. licheniformis is fit for hydrolyzing ox-like serum egg whites, collagen, and elastin. Despite what might be expected, a thermostable protease orchestrated by Cryzosphorium keratinophilum is dynamic just towards keratin. The utilization of keratinolytic proteins from thermophiles prompts expanded pace of keratin debasement. In addition, such keratinases typically have low collagenolytic movement, which are the necessities of enzymatic de-hairing in the calfskin industry. The traditional technique for de-hairing in a basic condition by treatment with sodium sulphide make issues of natural contamination. Properties of keratinases are reliant upon microorganism and blend of these proteins can be actuated by keratin added to the development media [17, 19, 23]. Fundamental for keratinases creation are development conditions, for example, $\mathrm{pH}$, temperature, and media organization. Most of known keratinases are extracellular or external film bound endopeptidases having a place with the serine protease family, however aspartic-, cysteine-and metallo-proteases are likewise discovered. Keratinases delivered by mesophilic microbes and saprophytic growths are generally dynamic at temperatures up to $50{ }^{\circ} \mathrm{C}$. Notwithstanding, in a couple cases, thermoactive protease which keep up with keratinolytic action at raised temperatures are delivered by a few mesophiles. Such wonder was seen on account of B. licheniformis K-19 creation, during development at $37{ }^{\circ} \mathrm{C}$; keratinolytic protease performed enzymatic action at temperatures from 30 to $90{ }^{\circ} \mathrm{C}$. This protease has most noteworthy action at $60^{\circ} \mathrm{C}$ and $\mathrm{pH}$ 7.5-8.0. Interestingly, protease from thermophilic Fervidobacterium islandicum AW-1 shows ideal keratinolytic movement at $100{ }^{\circ} \mathrm{C}$ and $\mathrm{pH} 9.0$, and has half-life of 90 min at $100^{\circ} \mathrm{C}$. The biodegradation utilizing refined keratinase could be supplanted by the activity of thermophilic microorganisms filling in response media or the utilization of culture filtrates containing the keratinase alone without microorganism cells [24]. This process is adequately productive and generally requires gentle conditions and more modest energy input, on the grounds that microbial decay creates heat during development $[14,19,25]$. It decreases the expenses of handling, and no pathogenic microbes (generally mesophiles) can develop at raised temperature. As of late, the bacterium Meiothermus ruber $\mathrm{H}-328$ was utilized for usage chicken plumes. Oxygen consuming development of this moderate thermophile at $55{ }^{\circ} \mathrm{C}$ for $6 \mathrm{~d}$ causes practically complete debasement of the quills into amino acids and oligopeptides [18, 23, 26]. He original conceivable utilization of keratinases and a few other microbial proteases is their utilization for debasement of irresistible type of prion proteins made through conglomeration to strange amyloid construction assigned as PrPSc [6, 12, 18]. Age of this structure causes ox-like spongiform encephalopathy (BSE) and Creutzfeldt-Jacob infection in human. Totalled prion atoms are firmly impervious to traditional proteases and various techniques utilized for microbe inactivation, including autoclaving at $121{ }^{\circ} \mathrm{C}$. Ongoing examinations have shown that amyloid type of prion can be corrupted by some microbial proteases using denaturing pre-treatments, like pre-warming and treatment with cleansers [21, 22, 28]. Promising wellspring of chemicals corrupting PrPSc without cleansers or under non-basic conditions are some thermophiles and microorganisms having a place with the family of Streptomyces [7, 9, 12, 23, 27, 28].

\section{CONCLUSION}

Following quite a while of exploration on thermoenzymes usage, it is currently viewed as that protein-based advancements for biomass changes are generally productive, practical and climate agreeable. Significant advancement has been made looking for extremophiles, yet their actual variety, has not yet been completely investigated. Thermostable enzymes disengaged from these living beings have shown their potential under conditions that are proper for bioconversion processes which play part in enterprises. The future difficulties for thermoenzymes creation incorporate innovations for enzymes biomass pre-treatment for better microbial assault, processes for practical creation of enzymes lastly creature advancement techniques to work on the properties of chemical to build their exercises, process resilience and warm solidness.

\section{FUNDING}

Nil

\section{AUTHORS CONTRIBUTIONS}

All the authors have contributed equally.

\section{CONFLICT OF INTERESTS}

Declared none

\section{REFERENCES}

1. Anand SS, Hawkes C, De Souza RJ, Mente A, Dehghan M, Nugent R, Zulyniak MA, Weis T, Bernstein AM, Krauss RM, Kromhout D, Jenkins DJA, Malik V, Martinez-Gonzalez MA, Mozaffarian D, Yusuf S, Willett WC, Popkin BM. Food consumption and its impact on cardiovascular disease: importance of solutions focused on the globalized food system: A report from the workshop convened by the World Heart Federation. J Am Coll Cardiol. 2015 Oct 6;66(14):1590-614. doi: 10.1016/j.jacc.2015.07.050, PMID 26429085.

2. Mane RS. Therapeutic applications of bioactive compounds obtained by endophytic Thielaviopsis basicola isolated from Ximenia americana, Western Ghats of India. J Microbiol Biotechnol Food Sci. 2020;9(5):870-8. doi: 10.15414/jmbfs.2020.9.5.870-878.

3. Acharya PB, Acharya DK, Modi HA. Optimization for cellulase production by Aspergillus niger using saw dust as substrate. Afr J Biotechnol. 2008;7(22):4147-52.

4. Zhang R, Naughton DP. Vitamin D in health and disease: current perspectives. Nutr J. 2010 Dec;9:65. doi: 10.1186/1475-28919-65, PMID 21143872.

5. Metchnikoff E. Lactic acid as inhibiting intestinal putrefaction. The prolongation of life: optimistic studies W. London: Heinemann; 1907. p. 161-83.

6. Tissier $H$. The treatment of intestinal infections by the method of transformation of the intestinal bacterial flora. C R Soc Biol. 1906;60:359-61.

7. Acharya S, Chaudhary A. Effect of nutritional and environmental factors on cellulases activity by thermophilic bacteria isolated from hot spring. J Sci Ind Res. 2011;70:142-8.

8. Ando S, Ishida H, Kosugi Y, Ishikawa K. Hyperthermostable endoglucanase from Pyrococcus horikoshii.Appl Environ Microbiol. 2002;68(1):430-3. doi: 10.1128/AEM.68.1.430433.2002, PMID 11772658.

9. Mane RS. Fungal endophytes: sources and prospects. J Med Plants Stud. 2018;6(2):121-6.

10. Andrade CMMC, Nei P Jr, Antranikian G. Extremely thermophilic microorganisms and their polymer hydrolytic enzymes. Braz J Microbiol. 1999;30:287-98.

11. Aro N, Ilmen M, Saloheimo A, Penttila M. ACEI is a repressor of cellulase and xylanase genes of Trichoderma reesei. Appl Environ Microbiol. 2002;69:56-65.

12. Mane RS, Paarakh PM, Vedamurthy AB. Brief review on fungal endophytes. Int J Second Metabolites. 2018;5(4):288-303. doi: 10.21448/ijsm.482798.

13. Aro N, Saloheimo A, Ilmén M, Penttilä M. ACEII, a novel transcriptional activator involved in regulation of cellulase and xylanase genes of Trichoderma reesei.J Biol Chem. 2001; 276(26):24309-14. doi: 10.1074/jbc.M003624200, PMID 11304525.

14. Dienes D, Egyhazi A, Reczey K. Treatment of recycled fiber with trichoderma cellulases. Ind Crops Prod. 2004;20(1):11-21. doi: 10.1016/j.indcrop.2003.12.009.

15. Egorova K, Antranikian G. Industrial relevance of thermophilic Archaea. Curr Opin Microbiol. 2005;8(6):649-55. doi: 10.1016/j.mib.2005.10.015, PMID 16257257. 
16. Fangdong Z. Study on the isolation of thermophilic cellulolytic bacteria by using 3 kinds of medium and the determination of its enzyme activity. J Anhui Agric Sci. 2008;36(15):6171-2.

17. Firn RD. Bioprospecting-why is it so unrewarding? Biodivers Conserv. 2003;12(2):207-16. doi: 10.1023/ A:1021928209813.

18. Fitter J. A measure of conformational entropy change during thermal protein unfolding using neutron spectroscopy. Biophys J. 2003;84(6):3924-30. doi: 10.1016/S0006-3495(03)75120-0, PMID 12770898.

19. Folan MA, Coughlan MP. The cellulase complex in the culture filtrate of the thermophyllic fungus, Talaromyces emersonii. Int J Biochem. 1978;9(10):717-22. doi: 10.1016/0020-711x(78)900381, PMID 710680.

20. Fracheboud D, Canevascini G. Isolation, purification, and properties of the exocellulase from Sporotrichum (Chrysosporium) thermophile. Enz Microb Technol. 1989;11(4):220-9. doi: 10.1016/0141-0229(89)90096-3.

21. Grogan DW. Evidence that beta-galactosidase of sulfolobus solfataricus is only one of several activities of a thermostable beta-d-glycosidase. Appl Environ Microbiol. 1991;57(6):16449. doi: 10.1128/aem.57.6.1644-1649.1991, PMID 16348503.

22. Vedamurthy $A B$, Mane RS. A new RoVe method to purify endophytic fungi from medicinal plants Western Ghats of Karnataka India. PCI- Approved-IJPSN. 2020;13(4):5011-9. doi: 10.37285/ijpsn.2020.13.4.7.
23. Gullo VP, McAlpine J, Lam KS, Baker D, Petersen F. Drug discovery from natural products. J Ind Microbiol Biotechnol. 2006;33(7):52331. doi: 10.1007/s10295-006-0107-2, PMID 16544162.

24. Hahn Hagerdal B, Galbe M, Gorwa Grauslund MF, Liden G, Zacchi G. Bio-ethanol-the fuel of tomorrow from the residues of today. Trends Biotechnol. 2006;24(12):549-56. doi: 10.1016/j.tibtech.2006.10.004, PMID 17050014.

25. Majamaa H, Isolauri E. Probiotics: a novel approach in the management of food allergy. J Allergy Clin Immunol. 1997;99(2):179-85. doi: 10.1016/s0091-6749(97)70093-9, PMID 9042042.

26. Isolauri E, Arvola T, Sutas Y, Moilanen E, Salminen S. Probiotics in the management of atopic eczema. Clin Exp Allergy. 2000;30(11):1604-10. doi: 10.1046/j.1365-2222.2000.00943.x, PMID 11069570

27. Bliznakov EG. Lipid-lowering drugs (statins), cholesterol, and coenzyme Q10. The Baycol case-a modern Pandora's box. Biomed Pharmacother. 2002;56(1):56-9. doi: 10.1016/s07533322(01)00150-0, PMID 11905511.

28. Mann GV. Studies of a surfactant and cholesteremia in the Maasai. Am J Clin Nutr. 1974;27(5):464-9. doi: 10.1093/ajcn/27.5.464, PMID 4596028.

29. Shaper AG, Jones KW, Jones M, Kyobe J. Serum lipids in three nomadic tribes of northern Kenya. Am J Clin Nutr. 1963;13:135-46. doi: 10.1093/ajcn/13.3.135, PMID 14061585.

30. Mane RS, Khatun MJ, Khalequzzaman KM, Neela FA. Fusarium wilts controlling revealed physiological and biochemical variations in tomato cultivar. Biosc Biotech Res Comm. 2020;13(3):1576-80. 